\title{
Skeletal Blood Flow in Bone Repair and Maintenance
}

\author{
Ryan E. Tomlinson ${ }^{1,2}$, Matthew J. Silva ${ }^{1,2}$ \\ ${ }^{1}$ Department of Orthopaedic Surgery, Washington University in St. Louis, Saint Louis, MO, USA; ${ }^{2}$ Musculoskeletal Research \\ Center, Washington University in St. Louis, Saint Louis, MO, USA
}

Bone is a highly vascularized tissue, although this aspect of bone is often overlooked. In this article, the importance of blood flow in bone repair and regeneration will be reviewed. First, the skeletal vascular anatomy, with an emphasis on long bones, the distinct mechanisms for vascularizing bone tissue, and methods for remodeling existing vasculature are discussed. Next, techniques for quantifying bone blood flow are briefly summarized. Finally, the body of experimental work that demonstrates the role of bone blood flow in fracture healing, distraction osteogenesis, osteoporosis, disuse osteopenia, and bone grafting is examined. These results illustrate that adequate bone blood flow is an important clinical consideration, particularly during bone regeneration and in at-risk patient groups.

Keywords: blood flow; angiogenesis; vascular remodeling; fracture; bone repair

Bone Research (2013) 4: 311-322. doi: 10.4248/BR201304002

\section{Introduction}

All biological tissues, including bone, require vascular support to survive. However, a frequently overlooked feature of bone is its extensive vascular network. Many studies have demonstrated that the blood vessels in bone are necessary for nearly all skeletal functions, including development, homeostasis, and repair (1). In addition, blood vessels lost due to trauma are regenerated, and new bone tissue formed in response to injury is vasc ularized. As a consequence of this environment, the blood vessels in bone are highly active, not simply a passive source for the delivery of nutrients (2). Readers are referred to recent public ations for more information about the active processes of the vasculature not covered in this review, including the vascular niche and hypoxia-driven signaling pathways (3-4).

The rate at which blood vessels deliveroxygen, nutrients, growth factors, and circulating cells to boneis tightly regulated as a function of blood pressure and vasculariza-

*Correspondence: Ryan E. Tomlinson; Matthew J. Silva E-mail: ryan.tomlinson@wustl.edu; silvam@wustl.edu Received 01 October 2013; Accepted 29 October 2013 tion. Given that blood pressure is generally maintained, the number and size of blood vessels determines the local blood flow rate. These two factors are regulated through the processes of angiogenesis and vasomotor function, respectively. Although a variety of skeletal disorders are associated with general vascular dysfunction (5-7), this review will focus on the regulation of bone blood flow, through the number and size of vessels, during bone repair and regeneration. To introduce this topic, the skeletal vascular a natomy and techniques for measuring bone blood flow are briefly disc ussed.

\section{Blood supply in bone}

A dense vascular network delivers oxygen and nutrients to all 206 bones in the human body. In general, this requiresa substantial portion of the total cardiac output. Experimental work in various animal species has demons trated that a significant portion of the resting cardiac output is directed to the skeleton, likely between $10 \%$ and $15 \%(8-12)$.

For some time, the blood flow pattem in bones has been described as primarily centrifugal: blood is supplied to the cortical bone through the nutrient arteries in the 
marrow cavity (Figure 1), and retumed by the periosteal veins (13). Particularly in long bones, the vascular anatomy is well characterized, with specific arterial inlets (the main nutrient artery, periosteal arteries, metaphyseal arteries, and epiphyseal arteries) and veinous outlets (14). However, the structure of the vascular network can vary greatly depending on the skeletal site. For example, arteries in the greater trochanter enter from the medial, lateral, and superior surfaces to supply a vascular network within the trochanter that is func tionally separated from the blood supply for the femoral neck and shaft (15).

In addition, there is evidence that the blood flow direction can shift from centrifugal to centripetal, depending on the hemodynamic conditions in the bone (16). This hypothesis was tested experimentally in the ovine tibia by intramedullary reaming (17). After the destruction of the ma in nutrient artery in the marrow cavity, blood flow at the periosteum was rapidly increased to compensate for the loss, generating local centripetal

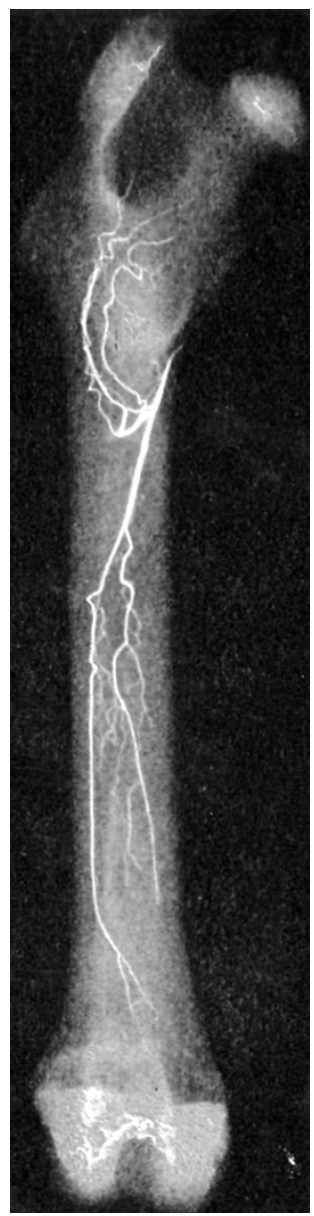

Figure 1 Femoral blood supply. The principal nutrient artery and its main medullary branches are shown in this angiograph of a rabbit femur (10). blood flow. More recently, stress fracture healing was associated with a disnuption of the normal centrifugal flow in the ulna, partic ularly the lacunocanalic ular flow (18). Although the skeletal vascular network is generally robust, some bones are poorly perfused. For example, stress fractures in the fifth metatarsal typic ally heal slowly due to the poor vascular support in this area (19-20). Additionally, bone blood flow, particularly in the long bones, is known to decrease with age (21-23). In summary, the blood flow conditions in bone are site-specific and dynamically change in response to trauma, metabolic demands, and aging.

\section{Mechanisms of vasc ulanization}

The production of bone, whether during development or repair, entails the generation of new blood vessels to support the tissue. There are at least four distinct mechanisms for producing new vessels. Vasculogenesis, or neovascularization, is the generation of de novo blood vessels (24), generally observed during development. In contrast, angiogenesis is a broad term used to describe the generation of new vessels from existing va sculature (25). Angiogenesis can be thought of both in terms of sprouting angiogenesis, the process by which a new vessel branches off from an existing vessel, as well as intussusc eptive angiogenesis, the process in which vessels split into two or more vessels (26). Finally, arteriogenesis is a separate process by which functional collateral arteries are generated between existing arteriolar anastomoses (27). Whereas angiogenesis is triggered by hypoxia through HIF-la mediated gene transcription, arteriogenesis appears to occur as a response to physical forces, independent of hypoxia (28).

The structural morphology of blood vessels can be altered by a process known as vascular remodeling (29). In general, vascular remodeling is either outward (increased vessel diameter) or inward (reduced vessel diameter). Remodeling can be further characterized as hypertrophic (increased cross-sectional area), hypotrophic (reduced cross-sectional area), or eutrophic (no change in cross-sectional area) (30). Vascular remodeling has been studied extensively in hypertensive rodents and humans (31-33), and this may be a mechanism by which blood flow isstably altered in bone (34-36).

On the other hand, short-term, rapid expansion (vasodilation) or contraction (vasoconstriction) of blood vessels, known as vasomotor or vascular tone, has also been implicated as a mechanism for rapidly changing blood flow rate, mostly in response to injury (37-38). The regulation of this process is complex and multifactorial, with important contributions from the autonomic nervous sys- 
tem and circulating homones, as well as locally produced factors that include nitric oxide (NO) and endostatin (39-40).

\section{Techniques formeasuring bone blood flow}

Like any fluid flow scenario, blood flow rate is quantified as volume pertime and is determined as the product of the cross-sectional area of the vessel and the fluid velocity, which depends on pressure. This relationship is expressed in Poiseuille's law, a simplification of the NavierStokes equations for laminar flow of incompressible, Newtonian fluids, as:

$$
Q=\frac{\pi r^{4} \Delta P}{8 \mu L}
$$

where flow rate $(Q)$ is given as a function of the radius of the vessel $(r)$, the difference in pressure $(\Delta P)$, the viscosity of the fluid $(\mu)$ and the length of the vessel (L). Although this equation is not appropriate for calculating absolute flow rates of blood, a non-Newtonian fluid, the general relationship illustrates that blood flow rate is weakly regulated by systemic blood pressure and strongly regulated by the local size of the blood vessel.

Vessel size and number can be robustly quantified ex vivo using histology or vascular casting (41). However, accurate quantification of in vivo blood flow, particularly in bone, is more diffic ult (42). Early attempts included the injection of red blood cells labeled using radioactive isotopes (43). As technology has improved, less onerous methods have been devised to provide more accurate results. The most important methods have been briefly summarized (Ta ble 1 ).

Administration of labeled microspheres into the circulation by arterial catheterization or cardiac injection has been used for some time to quantify blood flow (44). With a sufficiently small diameter $(<50 \mu \mathrm{m})$, the labeled microsphere will get trapped in the microvasculature. While the quantific ation method depends on the method of labeling, the number of mic rospheres must be determined in the tissue of interest as well as a reference tissue, making this technique relatively inva sive. Early on, mic rospheres were labeled using radioactivity (45), but non-radioactive microspheres have also been used, including colored microspheres and fluorescent microspheres (46). With suffic ient sampling, inherent error can be reduced to $20 \%$ or less (47). As a result, this tec hnique has been used in a wide range of experimental models (48-50) and is generally accepted as the "gold standard" for blood flow measurements, even in bone (2).

Laser Doppler flowmetry (DF) is qua ntita tive tec hnique developed to utilize the Doppler effect for determining the velocity of blood flow in a vessel (51-52). Real time blood flow rate can be measured continuously and non-invasively, but measurements can usually only be made in the most superficial vessels, typically in the skin, unless the procedure permits placing a probe inside the subject. Additionally, this technique does not provide anatomical data, so the region of interest must be determined extemally and changes in vascular a natomy are not captured. Despite considerable limita tions, this technique has been used successfully clinic ally and experimenta lly to quantify bone blood flow (53-54). Importantly, experimental work using $D F$ as well as simulta neous ${ }^{85} \mathrm{Sr}$ labeled microspheres found no statistically significant correlation between the two techniques in the femoral head or condyles, and suggested that DF may be a superior choice for quantifying bone blood flow (55). Recent validation and experimentation in the mouse tibia using LDF confims this opinion (56).

Positron emission tomography (PET) is a nother esta blished in vivo technique for quantifying rates of flow and meta bolism. The kinetic s of an injected, short-lived radioactive tracer are quantified by detecting the positron ejected during radioactive decay. Although the technology underpinning PET imaging was developed in the 1960s and 1970s, the utility of this tec hnique drama tic ally improved in the 1980s with the increased availability of radiophamaceuticals, including ${ }^{15} \mathrm{O}$ water typic ally used to evaluate blood flow (57). Since then, PET imaging has been used to evaluate blood flow in bone (58) a swell as a variety of soft tissues (59-62). In addition to providing blood flow rates in absolute units (63), simultaneous PET/ CTimaging can be registered to provide anatomic land-

Table 1 Comparison of blood flow measurement techniques

\begin{tabular}{llll}
\hline Factors & Microspheres & Laser Doppler Flowmetry & PETImaging \\
\hline Measurement Type & Static, relative to reference tissue & Continuous, quantitative & Continuous, absolute flow rates \\
Invasive? & Yes & No & No \\
Anatomical Data & Yes & No & Yes \\
OtherFactors & Experimentally diffic ult, general gold & Limited depth of scan & Limited by scan resolution and \\
& standard & may require invasive & availability of radioisotopes \\
& & probe placement & \\
\hline
\end{tabular}

www.boneresearch.org | Bone Research 
marks with high spatial resolution. A strong correlation between PET and mic rosphere injection was found when quantifying myocardial blood flow in rats $(P \varangle 0.0001)$ (64), but there has not been a similar study for bone blood flow comparison. The major limitation of PET imaging is resolution, though the most recent scanner technology is suitable for PET imaging in a nimals as small as rodents (65).

\section{Blood flow during fracture}

Skeletal fracture is typically associated with the disnuption of the surrounding soft tissue as well as the marrow compartment of long bones. As a result, the vascular network in and around bone is compromised. Decreased perfusion concurrent with the increased metabolic demands of repair leads to hypoxia near the fracture site (4). As a result, restoration of blood flow through angiogenic mechanisms is a key component of fracture healing, a process of endochondral ossific ation that largely rec a pitulates skeletal develop ment (66).

The relative importance of the main nutrient artery and the periosteal arteries during fracture healing has been debated for some time (67). Fixation of a canine tibial fracture with an intramedullary rod was shown to increase blood flow at the fracture site as compared to compression-plate fixation, suggesting that periosteal arteries are particularly responsive during fracture healing (68). This line of reasoning wasbolstered by a careful histological examination of vasculature following fracture that nic ely demonstrated the periosteal callus alone has extensive new vessel formation (69). Additionally, a body of experimental work has shown that the presence or absence of the periosteum signific antly affects the healing response (70). Finally, recent work has demonstrated that invading blood vessels in the periosteal fracture callus are intimately associated with osteoblast precursors (71). This finding confirms the importance of periosteal vascularity for the restoration of perfusion and the influx of cells providing osteogenic cues (Figure 2).

Although new blood vessels are certainly required for vascularizing the fracture callus and reversing vascular damage from the injury (72), regulation of the preexisting vascular network also playsan important role in the early stages of repair (73). In a study of two patients using PET imaging, blood flow rate was 3 to 6 times greater in the fractured tibia than the contralateral tibia 24 hours after injury, suggesting signific ant vasodila tion associated with the fracture (58). Using $D F$ to quantify blood flow rate, researchers demonstrated that the nitric oxide (NO) synthase inhibitor L-NAME only attenuated blood flow rate in the first day after tibial fracture (74). Thus, the initial vascular response following fracture is vasodilation of the intact vascular network through NO signaling, but the subsequent vascular response does not appear to be affected by decreased NO. This conclusion is consistent with work showing NOS expression and gene regulation is temporally modulated during fracture healing (75-76). Other experimental work has shown that endothelial vasodilation through NO signaling in bone is impaired with aging (77), suggesting vasomotor control may be a contributing factorfor poor fracture healing in the elderly. Other inflammatory cytokines, including TNF-a, IL-1, and IL-6, are expressed at the site of fracture and have been shown to affect repair, although their primary contribution is likely the migration and differentiation of progenitor cells, rather than the regulation of blood flow (78-80).

Many studies have highlighted the importance of pro-angiogenic factors, such as VEGF, HIF-1, and IGF, in fracture healing (81-84). However, the regulation of blood flow is complex, involving a balance of both proangiogenic and anti-angiogenic factors. An endogenous anti-angiogenic factor, endostatin, was recently examined following fracture healing (85). Administration of exogeneous endostatin decreased vascularity and hard callusformation, but soft callus formation was inc rea sed. These results underscore that more study is required to understand how the angiogenic pathways affect the entire fracture repair process.

Unlike the acute trauma of a complete fracture, repetitive loading of a bone can generate fatigue damage, eventually resulting in an incomplete, non-displaced fracture or stress fracture (86-87). In rodent models, stress fracture healing has been shown to recapitulate the intramembranous portion of fracture repair (88), with the hallmark of stress fracture healing being the rapid formation of a hard periosteal callus of woven bone without a cartilaginous template (89). As shown in Figure 3, significant periosteal angiogenesis is associated with healing (90-91), and angiogenic inhibition attenuates the healing response (92). By quantifying gold microspheres, an immediate increase in blood flow rate was observed following the generation of a stress fracture in rats (18), consistent with reports that inflammatory markers, including IL-1, IL-6, and NOS2, are upregulated as early as 1 hour after the injury (93-94). Using in vivo PET imaging, recent work has demonstrated that a n elevated blood flow rate is maintained at the site of a stress fracture by a two-step process of NOS-mediated vasodilation followed by angiogenesis, similar to a complete fracture (95). 


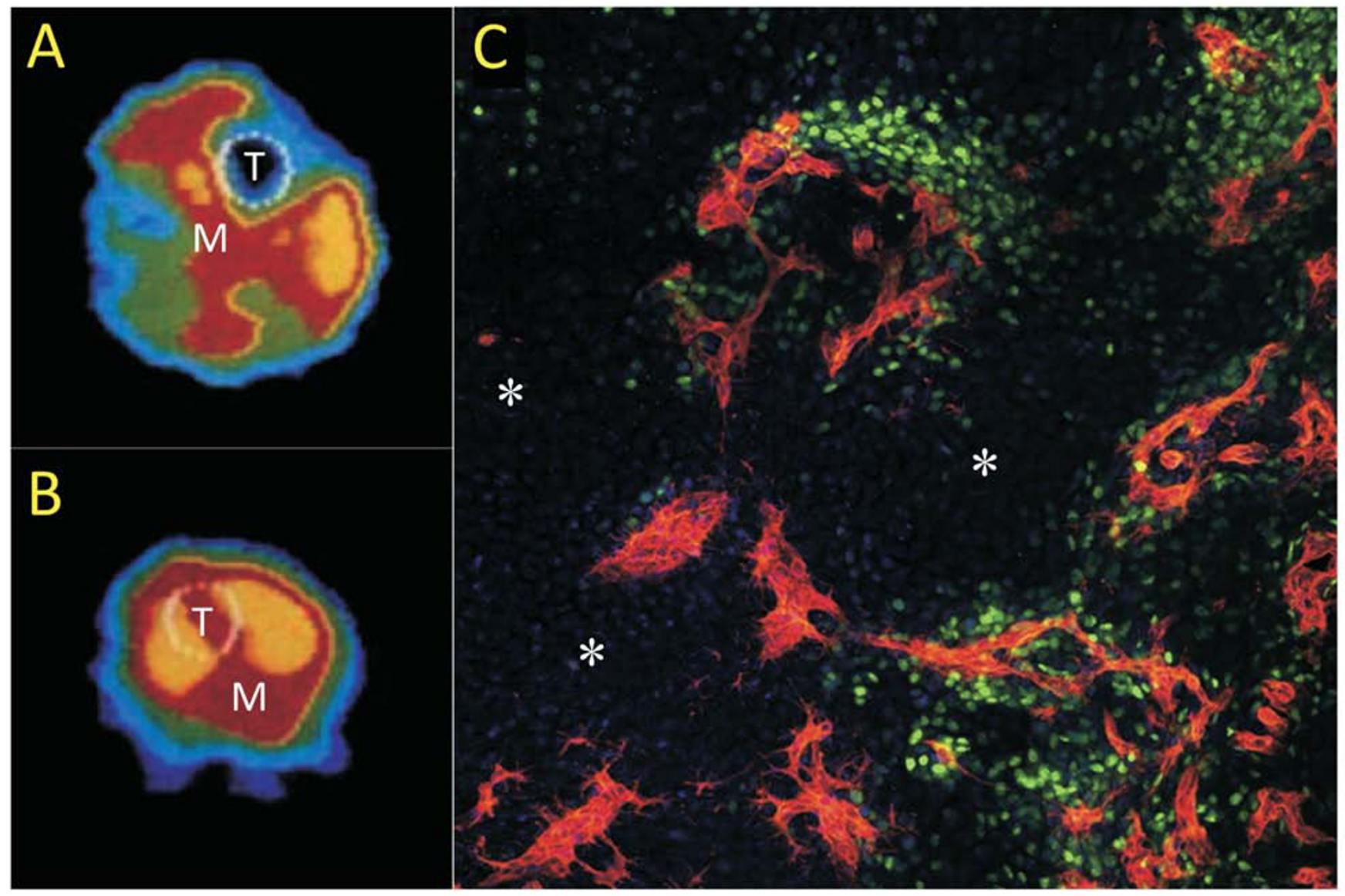

Figure 2 The vascular role in fracture. Blood flow rate was quantified using PET imaging after tibial fracture (58). A) In an uninjured limb, blood flow is highest in the muscle (M) near the tibia (T). B) In contrast, blood flow rate in and around the tibia (T) is markedly increased following fracture. This increase in blood flow rate is due in part to angiogenesis. Recent work has shown that these new blood vessels coinvade the cartilaginous template along with osteoblast precursors during endochondral fracture repair (71). C) In the periosteal fracture callus, Osx-expressing osteoprogenitors (green) are intimately associated with new vasculature (red) seven days after fracture. Pockets of avascular cartilage are labeled with a * Figures used with permission (License Number: 3266071128303).

\section{Blood flow during distraction osteogenesis}

Distraction osteogenesis (DO) is a regenerative procedure used to induce mostly non-endochrondral bone formation in long bones. This technique can be used c linic ally for leg lengthening (96) as well as the correction of pseudoarthroses (97), but has also been implemented in animal models to study the controlled formation of bone (98). The large increases in vascularity, associated with significant increases in pro-angiogenic gene transcription, were hypothesized to play an important role in bone formation during distraction (99). Treatment with the anti-angiogenic agent TNP-470 (100) as well as with antibodies against VEG F receptors (101) confimed this theory-inhibition of angiogenesis blocks bone formation in the distraction gap. This result is in contrast to other osteogenic programs that are only impaired by angio- genic inhibition, a phenomenon due in part to the fact that the distraction gap is functionally a vascular, having no preexisting vascular network. As a result, angiogenic inhibition completely blocks the migration of the osteoprogenitors that initiate bone formation. Consistent with this hypothesis, mice with overexpression of HIF-la in the osteoblastic lineage had markedly increased bone regeneration following distraction due to significantly increased angiogenesis in the distraction gap (83).

While most research has been limited to the vascular network that is generated in the distraction gap following DO, recent work has shown that these vessels are part of a larger vascular network that extends from the musc les near the surgic al site (102). In partic ular, arteriogenesis in the muscle compartment precedes angiogenesis that occurs in conjunction with bone formation. Importantly, the large vessels expressing smooth muscle 

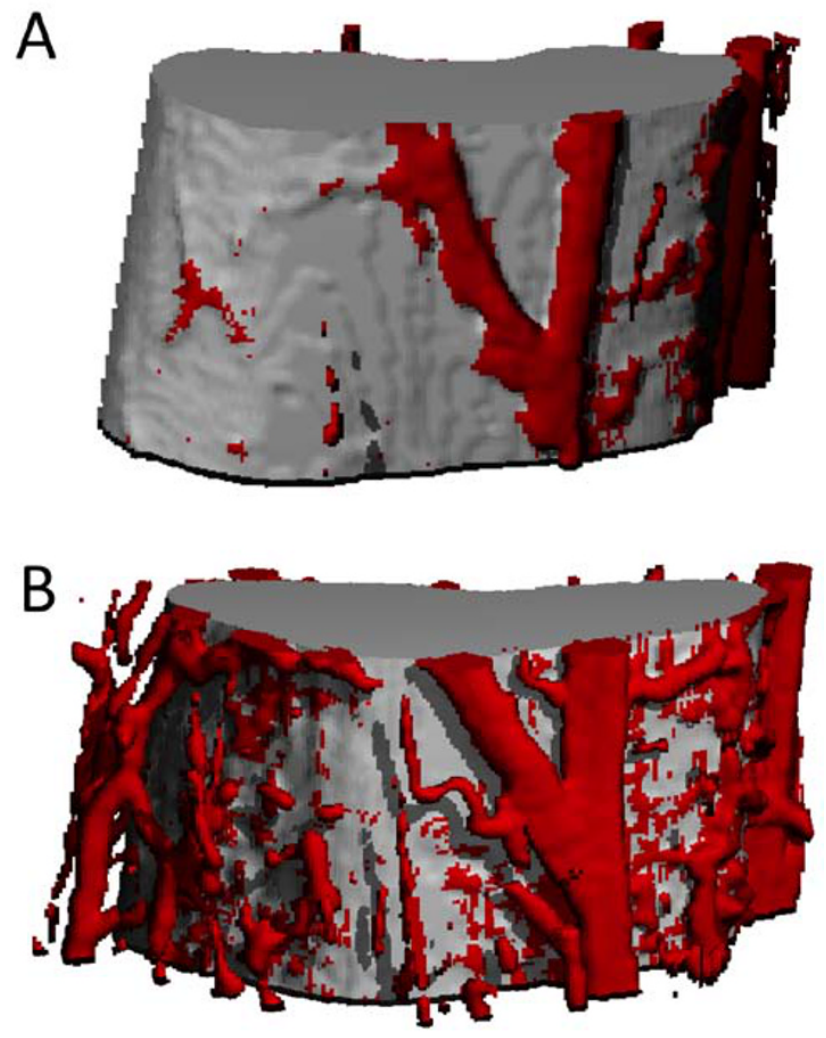

cular risk factors, in addition to standard therapy, would reduce the risk of osteoporotic fracture (105). In a recent study of 103 postmenopausal women, patients with osteoporosis were found to have increased arterial stiffness compared to patients with nomal BMD (106). In addition, a trend fordecreased spine BMD with increased carotid stiffness was observed. However, the relationship between the multifactorial disease states of osteoporosis and vascular dysfunction remains elusive, with recent evidence to suggest that osteoporosis may actually be a risk factor for cardiovasc ular disea se (107).

Similarly, chronic unloading of the skeleton results in signific ant decreases in bone mass $(21,108)$. Importantly, even a short period of skeletal unloa ding has been associated with significant decreases in bone blood flow (109). In a recent study, rats were subjected to 7 or 14 days of hindlimb unloading, then blood flow and vascular resistance were quantified following reloading (35). Decreased blood flow and increased vascular resistance were associated with unloading, suggesting that skeletal loading is required to ma inta in vascularfunction in bone. This response a ppears to have been mediated through arterial remodeling, a powerful and largely unexplored mechanism in bone (Figure 4).

The response to hindlimb unloading is similar to what has been observed in streptozotoc in-diabetic rats (110).

Figure 3 Rapid angiogenesis after bone injury. Damaging mechanical In this scenario, bone blood flow is significantly decreased while bone tumover is a Imost totally suppressed. In contrast, the significant increase in bone tumover in ovariectomized rodents has been associated with significant decreases in bone blood flow in a variety of studiesusing multiple techniques (111-114). However, this vascular effect has been shown to strongly depend on genetic background (56), potentially explaining controversial reports of increased bone blood flow following rodent ovariectomy by quantifying microspheres (115-116). Finally, other rodent models of rapidly induced osteopenia, such as paraplegia (117) and orchidectomy (118), have increased bone blood flow in the face of rapid bone loss. Determining the relationship between bone blood flow and fomation/resorption is highly desirable, but the signaling that regulates these mechanisms is not well understood (1). Additional work on the interaction and regulation of the bone and vascular compartments, particularly during acute and chronic bone loss, is nec essary.

\section{Blood flow in bone grafts}

Sufficient bone blood flow must be maintained for the successful repair of large skeletal defects using bone grafts (119-120). Since the late 1970s, vasc ularized fibular 

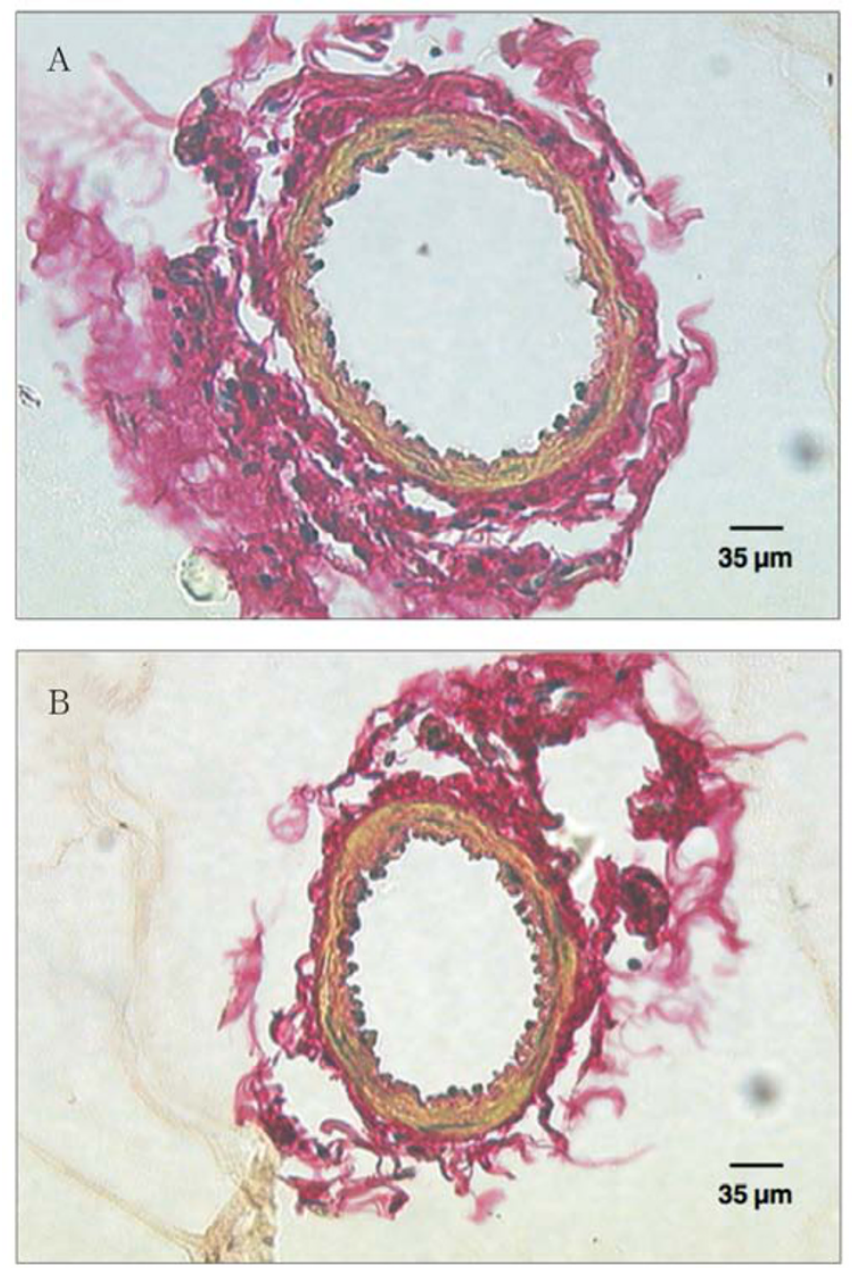

Figure 4 Vascular remodeling after unloading. Following cannulation with micropipettes, the diameter of the primary nutrient artery was measured in A) control and B) 14 day hindlimb unloaded animals (35). These results demonstrate that blood flow is decreased following chronic skeletal unloading by vascular remodeling. Figures used with permission (License Number: 3260231186916).

bone (VFB) grafts have been used to treat osteonecrosis of the femoral head (121). In this procedure, a portion of the fibula is removed intact with the attached vasculature and inserted into a cavity created in the osteonecrotic femoral head (122). In a recent review, VFB grafts were found to be superior to other grafting techniques, with better clinic al outc omes and fewer patients that progress to total joint replacement (123). However, VFB grafts are generated from the patient's own fibula, resulting in additional morbidity associated with the procedure. As a result, current tissue engineening efforts focus on developing synthetic bone grafts with preformed, functional vasc ular networks (124-125). Before implantation, mineral deposition in these grafts is spatially asso- ciated with the vascular network, consistent with the hypothesis that vascularized bone grafts improve subsequent bone formation (126). Improvements in this important area of regenerative medic ine will rely on previous research of bone blood flow, as researchers hunt for the right combination of scaffold, cell source, and growth factors.

\section{Clinical relevance}

Because bone blood flow affects bone regeneration following injury, patient populations with poor vascular function may have a slower recovery of fracture resistance than expected. This extra recovery time creates an additional risk of reinjury following skeletal damage. This issue is particularly problematic in cancer patients, since fracture risk is already elevated (127-128) and anti-angiogenic therapy is a widespread therapy for many cancers (129-130). Additionally, patients with diabetes (131-132), COPD (133), and sickle cell disease (134) as well as smokers (135) have vascular dysfunction that has been associated with skeletal defects. As a result, the maintenance of adequate vascular function during recovery from skeletal injury should receive additional consideration in these patient groups. Finally, patients should be advised that a healthy cardiovascular system is crucial for the long-tem prevention of osteoporosis.

\section{Conclusion}

Although the knowledge of vascular anatomy in the skeleton has greatly increased since the mic rosc op ists of the $16^{\text {th }}$ and $17^{\text {th }}$ centuries first revealed blood vessels in calcified tissue (2), the role that blood flow plays to regulate important physiological processes of bone regeneration and maintenance is still being discovered. In general, bone blood flow is robust and centripetal. Following a skeletal injury, blood flow is increased by angiogenesis. If metabolic demand is decreased, blood flow is decreased by vascular remodeling (Figure 5). However, the processes that disupt and reverse bone blood flow have not been well characterized, particularly in regards to skeletal healing. The importance of an intact vascular network following injury is beginning to be realized, with experimental results demonstrating that inflammation-mediated vasodilation provides a critical source of additional blood flow before revascularization begins. Similarly, the contribution of musc le to bone blood flow during healing may be important, since the blood vessel network that vascularizes bone during regeneration has been observed to be an extension of the blood vessel network in adjacent muscle. The reports of blood 
flow regulation in osteoporotic patients, disuse osteopenia, and models of rapid bone loss underscore the idea that bone blood flow is rapidly and dynamically regulated. In summary, more study is required to understand the important role of bone blood flow as researchers generate new therapiesfor skeletal regeneration and maintenance.

\section{Acknowledgments}

Supported by grants from the National Institutes of Health (R01 AR050211; P30 AR057235).

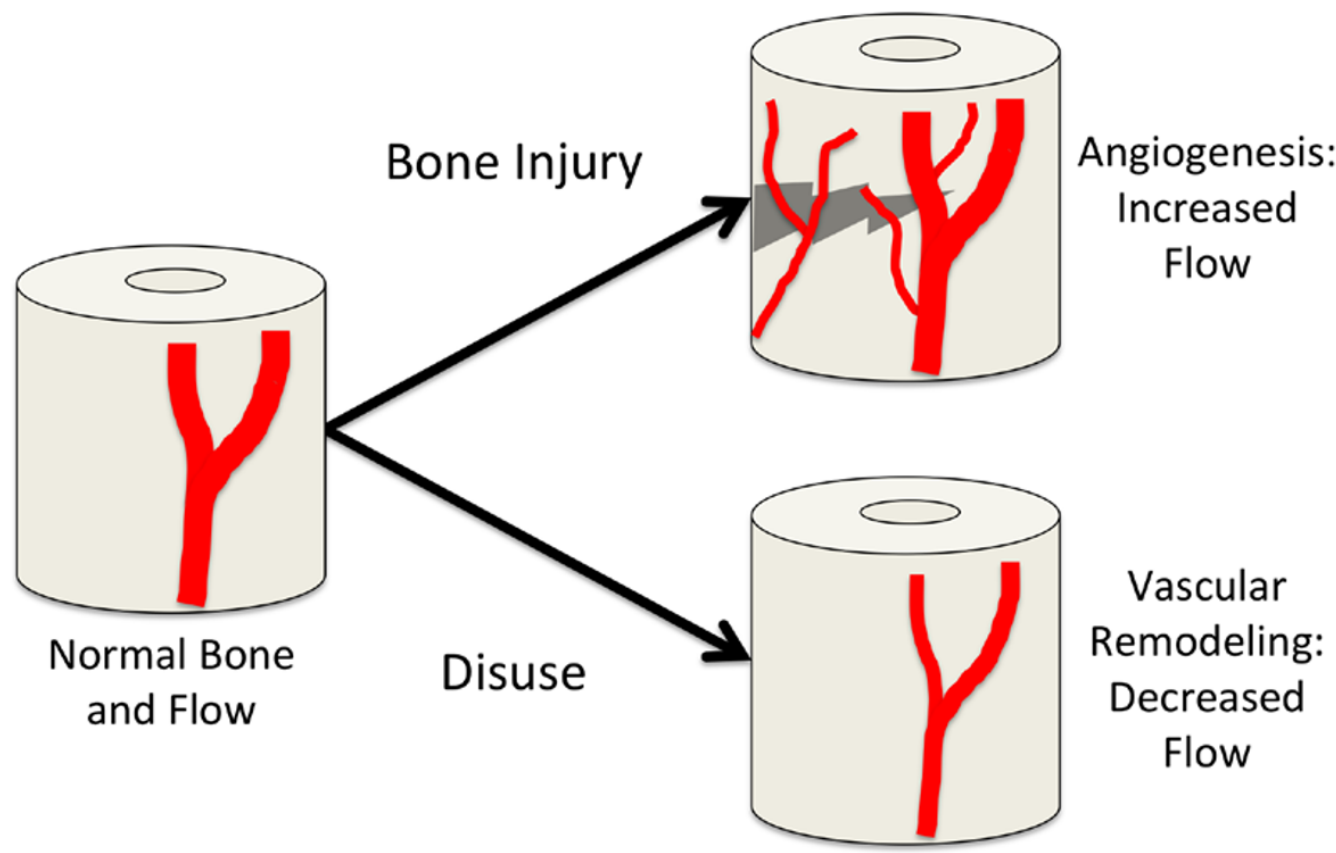

Figure 5 Vascular responses in bone. In this schematic, normal bone blood flow is represented on the left. In response to bone injury, such as a fracture, robust angiogenesis occurs to relieve oxygen tension and transport osteoprogenitor cells for repair. In contrast, bone disuse can result in decreased blood flow by vascular remodeling.

\section{References}

1 Brandi ML, Collin-Osdoby P. Vascular biology and the skeleton. J Bone Miner Res. 2006;21:183-192.

2 McCarthy I. The physiology of bone blood flow: a review. J Bone Joint Surg Am. 2006;88 Suppl 3:4-9.

3 Marenzana M, Arnett TR. The key role of the blood supply to bone. Bone Res. 2013;3:203-215.

4 Maes C, Carmeliet G, Schipani E. Hypoxia-driven pathways in bone development, regeneration and disease. Nat Rev Rheumatol. 2012;8:358-366.

5 Burkhardt R, Kettner G, Bohm W, Schmidmeier M, Schlag R, Frisch B, Mallmann B, Eisenmenger W, Gilg T. Changes in trabecular bone, hematopoiesis and bone marrow vessels in aplastic anemia, primary osteoporosis, and old age: a comparative histomorphometric study. Bone. 1987;8:157-164.

6 Reeve J, Arlot M, Wootton R, Edouard C, Tellez M, Hesp R, Green JR, Meunier PJ. Skeletal blood flow, iliac histomorphometry, and strontium kinetics in osteoporosis: a relationship between blood flow and corrected apposition rate. J Clin Endocrinol Metab.
1988;66:1124-1131.

7 Kerachian MA, Harvey EJ, Cournoyer D, Chow TY, Seguin C. Avascular necrosis of the femoral head: vascular hypotheses. Endothelium. 2006;13:237-244

8 Cummings EG. Breath holding at beginning of exercise. J Appl Physiol. 1962;17:221-224.

9 Kane WJ, Grim E. Blood flow to canine hind-limb bone, muscle, and skin. A quantitative method and its validation. J Bone Joint Surg Am. 1969;51:309-322.

10 Brookes $\mathrm{M}$. The blood supply of bone: an approach to bone biology. London: Butterworth. 1971:338.

11 Charkes ND, Makler PT Jr, Philips C. Studies of skeletal tracer kinetics. I. Digital-computer solution of a five-compartment model of [18F] fluoride kinetics in humans. J Nucl Med. 1978;19:13011309.

12 Gross PM, Marcus ML, Heistad DD. Measurement of blood flow to bone and marrow in experimental animals by means of the microsphere technique. J Bone Joint Surg Am. 1981;63:1028-1031.

13 Brookes M. Approaches to non-invasive blood flow measurement in bone. Biomed Eng. 1974;9:342-347. 
14 Johnson EO, Soultanis K, Soucacos PN. Vascular anatomy and microcirculation of skeletal zones vulnerable to osteonecrosis: vascularization of the femoral head. Orthop Clin North Am. 2004; 35:285-291.

15 Churchill MA, Brookes M, Spencer JD. The blood supply of the greater trochanter. J Bone Joint Surg Br. 1992;74:272-274.

16 Trias A, Fery A. Cortical circulation of long bones. J Bone Joint Surg Am. 1979;61:1052-1059.

17 Reichert IL, McCarthy ID, Hughes SP. The acute vascular response to intramedullary reaming. Microsphere estimation of blood flow in the intact ovine tibia. J Bone Joint Surg Br. 1995; 77:490-493.

18 Muir P, Sample SJ, Barrett JG, McCarthy J, Vanderby R Jr, Markel MD, Prokuski LJ, Kalscheur VL. Effect of fatigue loading and associated matrix microdamage on bone blood flow and interstitial fluid flow. Bone. 2007;40:948-956.

19 Smith JW, Arnoczky SP, Hersh A. The intraosseous blood supply of the fifth metatarsal: implications for proximal fracture healing. Foot Ankle. 1992;13:143-152.

20 Raghavan P, Christofides E. Role of teriparatide in accelerating metatarsal stress fracture healing: a case series and review of literature. Clin Med Insights Endocrinol Diabetes. 2012;5:39-45.

21 Bloomfield SA1, Hogan HA, Delp MD. Decreases in bone blood flow and bone material properties in aging Fischer-344 rats. Clin Orthop Relat Res. 2002;(396):248-257.

22 Kita K, Kawai K, Hirohata K. Changes in bone marrow blood flow with aging. J Orthop Res. 1987;5:569-575.

23 Lahtinen T, Alhava EM, Karjalainen P, Romppanen T. The effect of age on blood flow in the proximal femur in man. J Nucl Med. 1981;22:966-972.

24 Chappell JC, Wiley DM, Bautch VL. How blood vessel networks are made and measured. Cells Tissues Organs. 2012;195:94-107.

25 Risau W. Mechanisms of angiogenesis. Nature. 1997;386:671-674.

26 Makanya AN, Hlushchuk R, Djonov VG. Intussusceptive angiogenesis and its role in vascular morphogenesis, patterning, and remodeling. Angiogenesis. 2009;12:113-123.

27 Heil M, Eitenmuller I, Schmitz-Rixen T, Schaper W. Arteriogenesis versus angiogenesis: similarities and differences. J Cell Mol Med. 2006;10:45-55.

28 Pipp F, Boehm S, Cai WJ, Adili F, Ziegler B, Karanovic G, Ritter R, Balzer J, Scheler C, Schaper W, Schmitz-Rixen T. Elevated fluid shear stress enhances postocclusive collateral artery growth and gene expression in the pig hind limb. Arterioscler Thromb Vasc Biol. 2004;24:1664-1668.

29 Baumbach GL, Heistad DD. Remodeling of cerebral arterioles in chronic hypertension. Hypertension. 1989;13:968-972.

30 Mulvany MJ, Baumbach GL, Aalkjaer C, Heagerty AM, Korsgaard N, Schiffrin EL, Heistad DD. Vascular remodeling. Hypertension. 1996;28:505-506.

31 Intengan HD, Schiffrin EL. Vascular remodeling in hypertension: roles of apoptosis, inflammation, and fibrosis. Hypertension. 2001; 38:581-587.
32 Li JS, Knafo L, Turgeon A, Garcia R, Schiffrin EL. Effect of endothelin antagonism on blood pressure and vascular structure in renovascular hypertensive rats. Am J Physiol. 1996;271:H88H93.

33 Korsgaard N, Aalkjaer C, Heagerty AM, Izzard AS, Mulvany MJ Histology of subcutaneous small arteries from patients with essential hypertension. Hypertension. 1993;22:523-526.

34 Woolard J, Bevan HS, Harper SJ, Bates DO. Molecular diversity of VEGF-A as a regulator of its biological activity. Microcirculation. 2009;16:572-592.

35 Stabley JN, Prisby RD, Behnke BJ, Delp MD. Chronic skeletal unloading of the rat femur: Mechanisms and functional consequences of vascular remodeling. Bone. 2013;57:355-360.

36 Maes C. Role and regulation of vascularization processes in endochondral bones. Calcif Tissue Int. 2013;92:307-323.

37 Pohl U, Holtz J, Busse R, Bassenge E. Crucial role of endothelium in the vasodilator response to increased flow in vivo. Hypertension. 1986;8:37-44.

38 Sherwood ER, Toliver-Kinsky T. Mechanisms of the inflammatory response. Best Pract Res Clin Anaesthesiol. 2004;18:385-405.

39 Lamas S, Rodriguez-Puyol D. Endothelial control of vasomotor tone: the kidney perspective. Semin Nephrol. 2012; 32:156-166.

40 Wenzel D, Schmidt A, Reimann K, Hescheler J, Pfitzer G, Bloch W, Fleischmann BK. Endostatin, the proteolytic fragment of collagen XVIII, induces vasorelaxation. Circ Res. 2006;98:1203-1211.

41 Roche B, David V, Vanden-Bossche A, Peyrin F, Malaval L, Vico L, Lafage-Proust MH. Structure and quantification of microvascularisation within mouse long bones: what and how should we measure? Bone. 2012;50:390-399.

42 Tothill P. Bone blood flow measurement. J Biomed Eng. 1984;6: 251-256.

43 Brookes M. Blood flow rates in compact and cancellous bone, and bone marrow. J Anat. 1967;101:533-541.

44 Rudolph AM, Heymann MA. Validation of the antipyrine method for measuring fetal umbilical blood flow. Circ Res. 1967;21:185- 190.

45 Heymann MA, Payne BD, Hoffman JI, Rudolph AM. Blood flow measurements with radionuclide-labeled particles. Prog Cardiovasc Dis. 1977;20:55-79.

46 Prinzen FW, Glenny RW. Developments in non-radioactive microsphere techniques for blood flow measurement. Cardiovasc Res. 1994;28:1467-1475.

47 Buckberg GD, Luck JC, Payne DB, Hoffman JI, Archie JP, Fixler DE. Some sources of error in measuring regional blood flow with radioactive microspheres. J Appl Physiol. 1971;31:598-604.

48 Nitzsche EU, Choi Y, Czernin J, Hoh CK, Huang SC, Schelbert HR. Noninvasive quantification of myocardial blood flow in humans. A direct comparison of the [13N]ammonia and the [15O]water techniques. Circulation. 1996;93:2000-2006.

49 Deveci D, Egginton S. Development of the fluorescent microsphere technique for quantifying regional blood flow in small mammals. Exp Physiol. 1999;84:615-630.

50 Banai S, Jaklitsch MT, Shou M, Lazarous DF, Scheinowitz M, Biro 
S, Epstein SE, Unger EF. Angiogenic-induced enhancement of collateral blood flow to ischemic myocardium by vascular endothelial growth factor in dogs. Circulation. 1994; 89:2183-2189.

51 Hellem S, Jacobsson LS, Nilsson GE. Microvascular response in cancellous bone to halothane-induced hypotension in pigs. Int J Oral Surg. 1983;12:178-185.

52 Oberg PA. Laser-Doppler flowmetry. Crit Rev Biomed Eng. 1990; 18:125-163.

53 Notzli HP, Muller SM, Ganz R. [The relationship between fovea capitis femoris and weight bearing area in the normal and dysplastic hip in adults: a radiologic study]. Z Orthop Ihre Grenzgeb. 2001;139:502-506

54 Liu Q, Chen Z, Terry T, McNatt JM, Willerson JT, Zoldhelyi P. Intra-arterial transplantation of adult bone marrow cells restores blood flow and regenerates skeletal muscle in ischemic limbs. Vasc Endovascular Surg. 2009;43:433-443.

55 Swiontkowski MF, Tepic S, Perren SM, Moor R, Ganz R, Rahn BA. Laser Doppler flowmetry for bone blood flow measurement: correlation with microsphere estimates and evaluation of the effect of intracapsular pressure on femoral head blood flow. J Orthop Res. 1986;4:362-371.

56 Roche B, Vanden-Bossche A, Normand M, Malaval L, Vico L, Lafage-Proust MH. Validated Laser Doppler protocol for measurement of mouse bone blood perfusion-response to age or ovariectomy differs with genetic background. Bone. 2013;55:418-426.

57 Schelbert HR, Phelps ME, Hoffman E, Huang SC, Kuhl DE. Regional myocardial blood flow, metabolism and function assessed noninvasively with positron emission tomography. Am J Cardiol. 1980;46:1269-1277.

58 Ashcroft GP, Evans NT, Roeda D, Dodd M, Mallard JR, Porter RW, Smith FW. Measurement of blood flow in tibial fracture patients using positron emission tomography. J Bone Joint Surg Br. 1992;74:673-677.

59 Kubo S, Yamamoto K, Magata Y, Iwasaki Y, Tamaki N, Yonekura Y, Konishi J. Assessment of pancreatic blood flow with positron emission tomography and oxygen-15 water. Ann Nucl Med. 1991; 5:133-138.

60 de Langen AJ, Lubberink M, Boellaard R, Spreeuwenberg MD, Smit EF, Hoekstra OS, Lammertsma AA. Reproducibility of tumor perfusion measurements using 15O-labeled water and PET. J Nucl Med. 2008;49:1763-1768.

61 Rimoldi O, Schafers KP, Boellaard R, Turkheimer F, Stegger L, Law MP, Lammerstma AA, Camici PG. Quantification of subendocardial and subepicardial blood flow using 15O-labeled water and PET: experimental validation. J Nucl Med. 2006;47: 163-172.

62 Raichle ME, Martin WR, Herscovitch P, Mintun MA, Markham J. Brain blood flow measured with intravenous H2(15)O. II. Implementation and validation. J Nucl Med. 1983;24:790-798.

63 Bergmann SR, Herrero P, Markham J, Weinheimer CJ, Walsh MN. Noninvasive quantitation of myocardial blood flow in human subjects with oxygen-15-labeled water and positron emission tomography. J Am Coll Cardiol. 1989;14:639-652.

64 Herrero P, Kim J, Sharp TL, Engelbach JA, Lewis JS, Gropler RJ Welch MJ. Assessment of myocardial blood flow using 15O-water and 1-11C-acetate in rats with small-animal PET. J Nucl Med. 2006;47:477-485

65 Tomlinson RE, Silva MJ, Shoghi KI. Quantification of skeletal blood flow and fluoride metabolism in rats using PET in a preclinical stress fracture model. Mol Imaging Biol. 2012;14:348-354.

66 Gerstenfeld LC, Cullinane DM, Barnes GL, Graves DT, Einhorn TA. Fracture healing as a post-natal developmental process: molecular, spatial, and temporal aspects of its regulation. J Cell Biochem. 2003;88:873-884

67 Trueta J. Blood supply and the rate of healing of tibial fractures. Clin Orthop Relat Res. 1974;(105):11-26.

68 Rand JA, An KN, Chao EY, Kelly PJ. A comparison of the effect of open intramedullary nailing and compression-plate fixation on fracture-site blood flow and fracture union. J Bone Joint Surg Am. 1981;63:427-442

69 Brighton CT, Hunt RM. Early histological and ultrastructural changes in medullary fracture callus. J Bone Joint Surg Am. 1991; 73:832-847.

70 Colnot C, Zhang X, Knothe Tate ML. Current insights on the regenerative potential of the periosteum: molecular, cellular, and endogenous engineering approaches. J Orthop Res. 2012; 30:18691878.

71 Maes C, Kobayashi T, Selig MK, Torrekens S, Roth SI, Mackem S, Carmeliet G, Kronenberg HM. Osteoblast precursors, but not mature osteoblasts, move into developing and fractured bones along with invading blood vessels. Dev Cell. 2010;19:329-344.

72 Hausman MR, Schaffler MB, Majeska RJ. Prevention of fracture healing in rats by an inhibitor of angiogenesis. Bone. 2001;29: $560-564$.

73 Corbett SA, Hukkanen M, Batten J, McCarthy ID, Polak JM Hughes SP. Nitric oxide in fracture repair. Differential localisation, expression and activity of nitric oxide synthases. J Bone Joint Surg Br. 1999;81:531-537.

74 Corbett SA, McCarthy ID, Batten J, Hukkanen M, Polak JM, Hughes SP. Nitric oxide mediated vasoreactivity during fracture repair. Clin Orthop Relat Res. 1999;(365):247-253.

75 Diwan AD, Wang MX, Jang D, Zhu W, Murrell GA. Nitric oxide modulates fracture healing. J Bone Miner Res. 2000;15:342-351.

76 Zhu W, Diwan AD, Lin JH, Murrell GA. Nitric oxide synthase isoforms during fracture healing. J Bone Miner Res. 2001;16:535540 .

77 Prisby RD, Ramsey MW, Behnke BJ, Dominguez JM 2nd, Donato AJ, Allen MR, Delp MD. Aging reduces skeletal blood flow, endothelium-dependent vasodilation, and NO bioavailability in rats. J Bone Miner Res. 2007;22:1280-1288.

78 Cho TJ, Gerstenfeld LC, Einhorn TA. Differential temporal expression of members of the transforming growth factor beta superfamily during murine fracture healing. J Bone Miner Res. 2001;17:513-520 
79 Kon T, Cho TJ, Aizawa T, Yamazaki M, Nooh N, Graves D, Gerstenfeld LC, Einhorn TA. Expression of osteoprotegerin, receptor activator of NF-kappaB ligand (osteoprotegerin ligand) and related proinflammatory cytokines during fracture healing. J Bone Miner Res. 2001;16:1004-1014.

80 Glass GE, Chan JK, Freidin A, Feldmann M, Horwood NJ, Nanchahal J. TNF-alpha promotes fracture repair by augmenting the recruitment and differentiation of muscle-derived stromal cells. Proc Natl Acad Sci U S A. 2011;108:1585-1590.

81 Street J, Bao M, deGuzman L, Bunting S, Peale FV Jr, Ferrara N, Steinmetz H, Hoeffel J, Cleland JL, Daugherty A, van Bruggen N, Redmond HP, Carano RA, Filvaroff EH. Vascular endothelial growth factor stimulates bone repair by promoting angiogenesis and bone turnover. Proc Natl Acad Sci U S A. 2002;99:9656-9661.

82 Keramaris NC, Calori GM, Nikolaou VS, Schemitsch EH, Giannoudis PV. Fracture vascularity and bone healing: a systematic review of the role of VEGF. Injury. 2008;39 Suppl 2:S45-S57.

83 Wan C, Gilbert SR, Wang Y, Cao X, Shen X, Ramaswamy G, Jacobsen KA, Alaql ZS, Eberhardt AW, Gerstenfeld LC, Einhorn TA, Deng L, Clemens TL. Activation of the hypoxia-inducible factor-1alpha pathway accelerates bone regeneration. Proc Natl Acad Sci U S A. 2008;105:686-691.

84 Steinbrech DS, Mehrara BJ, Saadeh PB, Greenwald JA, Spector JA, Gittes GK, Longaker MT. Hypoxia increases insulinlike growth factor gene expression in rat osteoblasts. Ann Plast Surg. 2000; 44:529-534; discussion 534-535.

85 Holstein JH, Karabin-Kehl B, Scheuer C, Garcia P, Histing T, Meier C, Benninger E, Menger MD, Pohlemann T. Endostatin inhibits Callus remodeling during fracture healing in mice. J Orthop Res. 2013;31:1579-1584.

86 Patel DR. Stress fractures: diagnosis and management in the primary care setting. Pediatr Clin North Am. 2010;57:819-827.

87 Shindle MK, Endo Y, Warren RF, Lane JM, Helfet DL, Schwartz EN, Ellis SJ. Stress fractures about the tibia, foot, and ankle. J Am Acad Orthop Surg. 2012;20:167-176.

88 Wohl GR, Towler DA, Silva MJ. Stress fracture healing: fatigue loading of the rat ulna induces upregulation in expression of osteogenic and angiogenic genes that mimic the intramembranous portion of fracture repair. Bone. 2009;44:320-330.

89 Uthgenannt BA, Kramer MH, Hwu JA, Wopenka B, Silva MJ. Skeletal self-repair: stress fracture healing by rapid formation and densification of woven bone. J Bone Miner Res. 2007;22:1548-1556.

90 Matsuzaki H, Wohl GR, Novack DV, Lynch JA, Silva MJ Damaging fatigue loading stimulates increases in periosteal vascularity at sites of bone formation in the rat ulna. Calcif Tissue Int. 2007;80:391-399.

91 McKenzie JA, Silva MJ. Comparing histological, vascular and molecular responses associated with woven and lamellar bone formation induced by mechanical loading in the rat ulna. Bone. 2011;48:250-258.

92 Tomlinson RE, McKenzie JA, Schmieder AH, Wohl GR, Lanza GM, Silva MJ. Angiogenesis is required for stress fracture healing in rats. Bone. 2013;52:212-219.

93 Kidd LJ, Stephens AS, Kuliwaba JS, Fazzalari NL, Wu AC, Forwood MR. Temporal pattern of gene expression and histology of stress fracture healing. Bone. 2010;46:369-378.

94 McKenzie JA, Bixby EC, Silva MJ. Differential gene expression from microarray analysis distinguishes woven and lamellar bone formation in the rat ulna following mechanical loading. PLoS One. 2011;6:e29328.

95 Tomlinson RE, Shoghi KI, Silva MJ. Nitric oxide mediated vasodilation increases blood flow during the early stages of stress fracture healing. J Appl Physiol (1985). 2013 Dec 19. [Epub ahead of print].

96 Ilizarov GA. Clinical application of the tension-stress effect for limb lengthening. Clin Orthop Relat Res. 1990;(250):8-26.

97 Dendrinos GK, Katsioulas K, Krallis PN, Lyritsis E, Papagiannopoulos G. [Treatment of femoral and tibial septic pseudarthrosis by internal lengthening. Apropos of 24 cases]. Rev Chir Orthop Reparatrice Appar Mot. 1995;80:44-50.

98 Jazrawi LM, Majeska RJ, Klein ML, Kagel E, Stromberg L, Einhorn TA. Bone and cartilage formation in an experimental model of distraction osteogenesis. J Orthop Trauma. 1998;12:111116.

99 Carvalho RS, Einhorn TA, Lehmann W, Edgar C, Al-Yamani A, Apazidis A, Pacicca D, Clemens TL, Gerstenfeld LC. The role of angiogenesis in a murine tibial model of distraction osteogenesis. Bone. 2004;34:849-861.

100 Fang TD, Salim A, Xia W, Nacamuli RP, Guccione S, Song HM, Carano RA, Filvaroff EH, Bednarski MD, Giaccia AJ, Longaker MT. Angiogenesis is required for successful bone induction during distraction osteogenesis. J Bone Miner Res. 2005;20:11141124.

101 Jacobsen KA, Al-Aql ZS, Wan C, Fitch JL, Stapleton SN, Mason ZD, Cole RM, Gilbert SR, Clemens TL, Morgan EF, Einhorn TA, Gerstenfeld LC. Bone formation during distraction osteogenesis is dependent on both VEGFR1 and VEGFR2 signaling. J Bone Miner Res. 2008;23:596-609.

102 Morgan EF, Hussein AI, Al-Awadhi BA, Hogan DE, Matsubara H Al-Alq Z, Fitch J, Andre B, Hosur K, Gerstenfeld LC. Vascular development during distraction osteogenesis proceeds by sequential intramuscular arteriogenesis followed by intraosteal angiogenesis. Bone. 2012;51:535-545.

103 Matsubara H, Hogan DE, Morgan EF, Mortlock DP, Einhorn TA, Gerstenfeld LC. Vascular tissues are a primary source of BMP2 expression during bone formation induced by distraction osteogenesis. Bone. 2012;51:168-180.

104 Vogt MT, Cauley JA, Kuller LH, Nevitt MC. Bone mineral density and blood flow to the lower extremities: the study of osteoporotic fractures. J Bone Miner Res. 1997;12:283-289.

105 Alagiakrishnan K, Juby A, Hanley D, Tymchak W, Sclater A. Role of vascular factors in osteoporosis. J Gerontol A Biol Sci Med Sci. 2003;58:362-366

106 Ageev FT, Barinova IV, Seredenina EM, Orlova Ia A, Kuz'mina 
AE, Masenko VP, Kochetov AG. [Osteoporosis and arterial stiffness: study of 103 women with mild to moderate risk of cardiovascular disease]. Kardiologiia. 2013;53:51-58.

107 Lampropoulos CE, Papaioannou I, D'Cruz DP. Osteoporosis--a risk factor for cardiovascular disease? Nat Rev Rheumatol. 2012; 8:587-598.

108 Leblanc AD, Schneider VS, Evans HJ, Engelbretson DA, Krebs JM. Bone mineral loss and recovery after 17 weeks of bed rest. J Bone Miner Res. 1990;5:843-850.

109 Colleran PN, Wilkerson MK, Bloomfield SA, Suva LJ, Turner RT, Delp MD. Alterations in skeletal perfusion with simulated microgravity: a possible mechanism for bone remodeling. J Appl Physiol (1985). 2000;89:1046-1054.

110 Lucas PD. Reversible reduction in bone blood flow in streptozotocin-diabetic rats. Experientia. 1987;43:894-895.

111 Deng M, Griffith JF, Zhu XM, Poon WS, Ahuja AT, Wang YX. Effect of ovariectomy on contrast agent diffusion into lumbar intervertebral disc: a dynamic contrast-enhanced MRI study in female rats. Magn Reson Imaging. 2012;30:683-688.

112 Ding WG, Wei ZX, Liu JB. Reduced local blood supply to the tibial metaphysis is associated with ovariectomy-induced osteoporosis in mice. Connect Tissue Res. 2011;52:25-29.

113 Griffith JF, Wang YX, Zhou H, Kwong WH, Wong WT, Sun YL, Huang Y, Yeung DK, Qin L, Ahuja AT. Reduced bone perfusion in osteoporosis: likely causes in an ovariectomy rat model. Radiology. 2010;254:739-746.

114 Mekraldi S, Lafage-Proust MH, Bloomfield S, Alexandre C, Vico L. Changes in vasoactive factors associated with altered vessel morphology in the tibial metaphysis during ovariectomy-induced bone loss in rats. Bone. 2003;32:630-641.

115 Egrise D, Martin D, Neve P, Vienne A, Verhas M, Schoutens A. Bone blood flow and in vitro proliferation of bone marrow and trabecular bone osteoblast-like cells in ovariectomized rats. Calcif Tissue Int. 1992;50:336-341.

116 Kapitola J, Andrle J, Kubícková J. Possible participation of prostaglandins in the increase in the bone blood flow in oophorectomized female rats. Exp Clin Endocrinol. 1994;102:414-416.

117 Verhas M, Martinello Y, Mone M, Heilporn A, Bergmann P, Tricot A, Schoutens A. Demineralization and pathological physiology of the skeleton in paraplegic rats. Calcif Tissue Int. 1980;30: 83-90.

118 Schoutens A, Verhas M, L'Hermite-Baleriaux M, L'Hermite M, Verschaeren A, Dourov N, Mone M, Heilporn A, Tricot A. Growth and bone haemodynamic responses to castration in male rats. Reversibility by testosterone. Acta Endocrinol (Copenh). 1984;107:428-432.

119 Pliefke J, Rademacher G, Zach A, Bauwens K, Ekkernkamp A, Eisenschenk A. Postoperative monitoring of free vascularized bone grafts in reconstruction of bone defects. Microsurgery. 2009; 29:401-407.

120 Banic A, Hertel R. Double vascularized fibulas for reconstruction of large tibial defects. J Reconstr Microsurg. 1993;9:421-428.

121 Aluisio FV, Urbaniak JR. Proximal femur fractures after free vascularized fibular grafting to the hip. Clin Orthop Relat Res. 1998;(356):192-201.

122 Gilbert A, Judet H, Judet J, Ayatti A. Microvascular transfer of the fibula for necrosis of the femoral head. Orthopedics. 1986;9:885890.

123 Fang T, Zhang EW, Sailes FC, McGuire RA, Lineaweaver WC, Zhang F. Vascularized fibular grafts in patients with avascular necrosis of femoral head: a systematic review and meta-analysis. Arch Orthop Trauma Surg. 2013;133:1-10.

124 Muller AM, Mehrkens A, Schafer DJ, Jaquiery C, Guven S, Lehmicke M, Martinetti R, Farhadi I, Jakob M, Scherberich A, Martin I. Towards an intraoperative engineering of osteogenic and vasculogenic grafts from the stromal vascular fraction of human adipose tissue. Eur Cell Mater. 2010;19:127-135.

125 Correia C, Grayson W, Eton R, Gimble JM, Sousa RA, Reis RL, Vunjak-Novakovic G. Human adipose-derived cells can serve as a single-cell source for the in vitro cultivation of vascularized bone grafts. J Tissue Eng Regen Med. 2012 Aug 17. [Epub ahead of print]

126 Hutton DL, Moore EM, Gimble JM, Grayson WL. Platelet-derived growth factor and spatiotemporal cues induce development of vascularized bone tissue by adipose-derived stem cells. Tissue Eng Part A. 2013;19:2076-2086.

127 Body JJ. Increased fracture rate in women with breast cancer: a review of the hidden risk. BMC Cancer. 2011;11:384.

128 Chen Z, Maricic M, Bassford TL, Pettinger M, Ritenbaugh C, Lopez AM, Barad DH, Gass M, Leboff MS. Fracture risk among breast cancer survivors: results from the Women's Health Initiative Observational Study. Arch Intern Med. 2005;165:552-558.

129 Mayer RJ. Two steps forward in the treatment of colorectal cancer. N Engl J Med. 2004;350:2406-2408.

130 Kubota Y. Tumor angiogenesis and anti-angiogenic therapy. Keio J Med. 2012;61:47-56

131 Hofbauer LC, Brueck CC, Singh SK, Dobnig H. Osteoporosis in patients with diabetes mellitus. J Bone Miner Res. 2007;22:13171328.

132 Oikawa A, Siragusa M, Quaini F, Mangialardi G, Katare RG, Caporali A, van Buul JD, van Alphen FP, Graiani G, Spinetti G, Kraenkel N, Prezioso L, Emanueli C, Madeddu P. Diabetes mellitus induces bone marrow microangiopathy. Arterioscler Thromb Vasc Biol. 2010;30:498-508.

133 Regan E, Jaramillo J. It's the fracture that matters -bone disease in COPD patients. COPD. 2012;9:319-321.

134 Miller RG, Segal JB, Ashar BH, Leung S, Ahmed S, Siddique S, Rice T, Lanzkron S. High prevalence and correlates of low bone mineral density in young adults with sickle cell disease. Am J Hematol. 2006;81:236-241.

135 Yoon V, Maalouf NM, Sakhaee K. The effects of smoking on bone metabolism. Osteoporos Int. 2012;23:2081-2092. 